\title{
Alaska ecosystem carbon fluxes estimated from MODIS satellite data inputs from 2000 to 2010
}

\author{
Christopher Potter $^{1 *}$, Steven Klooster ${ }^{1,2}$ and Vanessa Genovese ${ }^{1,2}$
}

\begin{abstract}
Background: Trends in Alaska ecosystem carbon fluxes were predicted from inputs of monthly MODerate resolution Imaging Spectroradiometer (MODIS) vegetation index time-series combined with the NASA-CASA (Carnegie Ames Stanford Approach) carbon cycle simulation model over the past decade. CASA simulates monthly net ecosystem production (NEP) as the difference in carbon fluxes between net primary production (NPP) and soil microbial respiration (Rh).

Results: Model results showed that NEP on a unit area basis was estimated to be highest ( $\left.>+10 \mathrm{~g} \mathrm{C} \mathrm{m}^{-2} \mathrm{yr}^{-1}\right)$ on average over the period 2000 to 2010 within the Major Land Resource Areas (MRLAs) of the Interior Brooks Range Mountains, the Arctic Foothills, and the Western Brooks Range Mountains. The lowest (as negative land C source fluxes) mean NEP fluxes were predicted for the MLRAs of the Cook Inlet Lowlands, the Ahklun Mountains, and Bristol Bay-Northern Alaska Peninsula Lowlands. High levels of interannual variation in NEP were predicted for most MLRAs of Alaska.

Conclusions: The relatively warm and wet years of 2004 and 2007 resulted in the highest positive NEP flux totals across MLRAs in the northern and western coastal locations in the state (i.e., the Brooks Range Mountains and Arctic Foothills). The relatively cold and dry years of 2001 and 2006 were predicted with the lowest (negative) NEP flux totals for these MLRAs, and likewise across the Ahklun Mountains and the Yukon-Kuskokwim Highlands.
\end{abstract}

Keywords: Net carbon flux, MODIS EVI, Ecosystems, Alaska

\section{Background}

Climate is changing worldwide, but Alaska is warming at a rate almost twice the global average [1]. Changes already observed in Alaskan landscapes include rapidly eroding shorelines, melting ground ice (permafrost), wetland drying, ice wedge degradation, increased shrub growth at high latitudes, and conifer forest decline [2-4]. Sustainable ecological function and threatened wildlife species are at risk throughout Alaska [5,6].

Satellite remote sensing has been shown to be an accurate method to monitor large-scale change of vegetation cover, especially following disturbance [7-10]. There have been numerous previous studies of satellite greenness index patterns in Alaska and arctic North America. For example, Jia et al. [11] analyzed 21 years (1981-2001) of AVHRR-NDVI (Advanced Very High Resolution

\footnotetext{
* Correspondence: chris.potter@nasa.gov

'NASA Ames Research Center, Mail Stop 232-21, Moffett Field, CA 94035, USA

Full list of author information is available at the end of the article
}

Radiometer - Normalized Difference Vegetation Index) data for three bio-climatic subzones in northern Alaska and confirmed a long-term trend of increase in vegetation greenness for the Alaskan tundra. This study reported a $17 \%$ increase in peak vegetation greenness across the region (corresponding to simultaneous increases in air temperatures), and field sampling throughout the region revealed that NDVI explained over $82 \%$ of total above-ground plant biomass. Goetz et al. [12,13] analyzed the seasonal and inter-annual variations of post-fire forest cover by using AVHRR-NDVI time-series across boreal North America and reported vegetation compositional changes consistent with early successional plant species and susceptibility to drought. Beck and Goetz [14] reported that increases in tundra productivity from satellite observations for the North Slope of Alaska do not appear restricted to areas of high shrub cover, and that enhanced productivity was found across mixed vegetation types that include graminoids [15].
C Biomed Central

(c) 2013 Potter et al.; licensee BioMed Central Ltd. This is an open access article distributed under the terms of the Creative Commons Attribution License (http://creativecommons.org/licenses/by/2.0), which permits unrestricted use, distribution, and reproduction in any medium, provided the original work is properly cited. 
Other mechanisms of change in tundra and boreal ecosystems have also been studied with remote sensing. In areas on the North Slope of Alaska where topography strongly controlled the flow and redistribution of surface water, NDVI change was found to be strongly related to the variability in the depth of the active (thawed) soil layers of tundra [16]. Kim et al. [17] further examined changing soil freeze-thaw signal from satellite microwave remote sensing and vegetation greenness patterns for the 9-year (2000-2008) vegetation record from satellites over North America, and reported that the relationship between the non-frozen period (June-August) and mean summer greenness index anomalies was generally positive for tundra and boreal forest areas of Canada.

Previous simulation modeling studies of carbon storage for Alaska estimated that terrestrial ecosystems have been a net sink (from the atmosphere) of between 5 and $12 \mathrm{Tg} \mathrm{C}$ ( $1 \mathrm{Tg}=10^{12}$ grams) $\mathrm{yr}^{-1}$ for the state land area in the 1980s, and between 0 and $10 \mathrm{Tg} \mathrm{C} \mathrm{yr}^{-1}$ during the 1990s $[18,19]$. Using a combination of field measurements and modeling approaches, O'Donnell et al. [20] estimated typical net accumulation rates of $23 \mathrm{~g} \mathrm{C} \mathrm{m}^{-2} \mathrm{yr}^{-1}$ and $57 \mathrm{~g} \mathrm{C} \mathrm{m}^{-2} \mathrm{yr}^{-1}$ in permafrost landforms and peat bog ecosystems, respectively, over the last 100 years in interior Alaska. Nonetheless, when wetland methane $\left(\mathrm{CH}_{4}\right)$ emissions were also considered (and expressed in $\mathrm{CO}_{2}$ equivalents) in the regional carbon budget, Zhuang et al. [19] estimated that Alaska's terrestrial ecosystems functioned as large net source of carbon greenhouse gases to the atmosphere during the period of 1980 to 1996.

In the present study, we utilized the Enhanced Vegetation Index (EVI) image data from NASA's MODerate resolution Imaging Spectroradiometer (MODIS) satellite sensor as inputs to the CASA (Carnegie Ames Stanford Approach) ecosystem carbon model for the state of Alaska from 2000 to 2010. The main research questions addressed in this study were:

- How has climate variability altered patterns of ecosystem carbon storage in Alaska, and what were the primary mechanisms driving these changes?

- Which ecosystems and landscape components in Alaska were most vulnerable to abrupt loss of ecosystem carbon over the past decade, and which were the most resistant to abrupt loss of ecosystem carbon?

\section{Results}

CASA validation with Alaska tower flux measurements

Flux estimates from eddy-correlation analysis were obtained from tower flux sites in Alaska that could meet certain criteria for CASA model comparisons [21]. First, at least three complete years of site flux measurements were required to evaluate model predictions of interannual variations in CASA NEP fluxes. Second, winter season NEP fluxes were required from a site to evaluate model predictions of soil $\mathrm{CO}_{2}$ emissions on a year-round basis. Third, tower sites were required to be representative of the predominant vegetation class setting in the MODIS land cover data used as input to the CASA model [22].

For sites meeting all of these criteria, data sets were obtained from the central data repository located at the Carbon Dioxide Information Analysis Center (CDIAC; http://public.ornl.gov/ameriflux/dataproducts.shtml). Level 4 AmeriFlux records contained gap-filled and $\mu$ star filtered records, complete with calculated gross productivity and total ecosystem respiration terms on varying time intervals including hourly, daily, weekly, and monthly with flags for the quality of the original and gap-filled data.

CASA monthly NEP predictions from the MOD13C2 EVI data values closest to the tower location were compared to AmeriFlux eddy-correlation monthly estimates of the corresponding NEP fluxes. We note that the monthly MODIS EVI values in practically every grid cell of the global CASA model will be influenced by periodic land cover disturbances and (some naturally occurring) areas of sparse vegetation cover, including development, roads, water bodies. It was expected, therefore, that CASA model NEP flux predictions would be systematically lower than tower measurements of these carbon fluxes, since tower footprints tend to be far less affected by historical wildfire and other disturbances (such as logging and forest thinning), compared for instance to the surrounding MODIS grid cell area in which they are located.

A total of three Ameriflux tower sites in Alaska (listed in Table 1), together reporting 107 monthly NEP flux measurements, were found to meet the criteria cited above for comparison to CASA model NEP predictions. Results showed that the CASA model predictions closely followed seasonal timing of tower measurements at each site (Figure 1). The linear regression correlation coefficient $\left(R^{2}\right)$ between CASA model NEP predictions and tower fluxes NEP was estimated at between $R^{2}=0.44$ and 0.60 (significant

Table 1 Ameriflux tower sites in Alaska selected for comparison to CASA monthly NEP flux predictions

\begin{tabular}{llllll}
\hline Sitename & Latitude & Longitude & Elevation $(\mathbf{m})$ & Vegetation cover & $\boldsymbol{R}^{\mathbf{2}}$ for CASA NEP \\
\hline Atqasuk & 70.4696 & -157.4089 & 15 & Permanent wetlands & 0.60 \\
Ivotuk & 68.4870 & -155.7480 & 568 & Open shrublands & 0.44 \\
Delta Junction 1920 control & 63.8881 & -145.7394 & 518 & Evergreen needleleaf forests & 0.65 \\
\hline
\end{tabular}




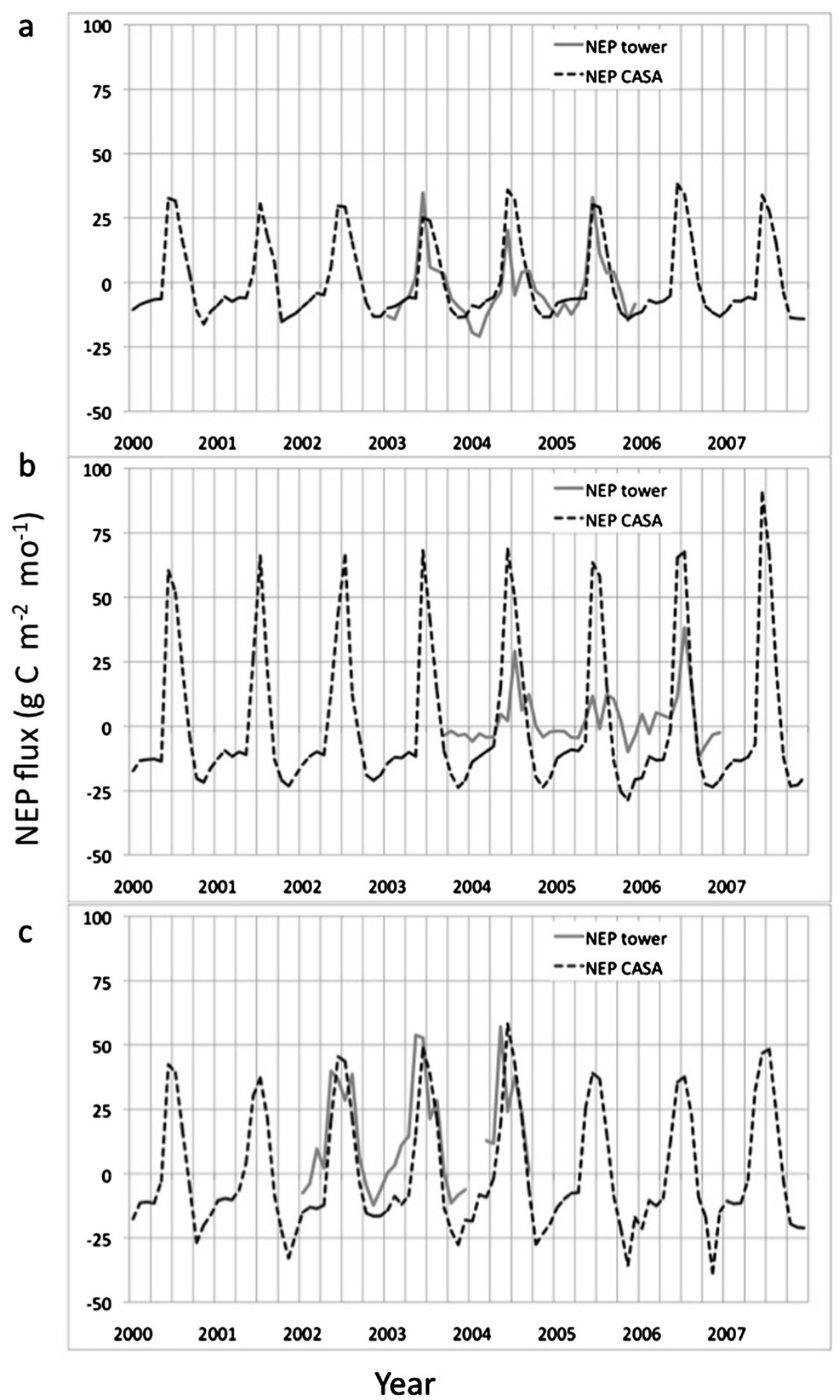

Figure 1 CASA monthly NEP predictions in comparison to compared to AmeriFlux eddy-correlation monthly estimates. (a) Atqasuk wetland, (b) Ivotuk shrubland, (c) Delta Junction forest. 
at $p<0.05)$ for the three sites. We note that the Level 4 AmeriFlux data reported for monthly NEP at the Ivotuk open tundra site in the Arctic Foothills (MLRA; [23], Figure 2) were not consistent in seasonal sign (as ecosystem source or sink of carbon flux) from year to year, which rendered those measured fluxes far less reliable for model comparisons than the other two AmeriFlux tower sites listed in Table 1. Previous publications have reported that these $R^{2}$ results are typical of model-tower flux comparisons, in large part because eddy flux measurements carry large uncertainties into the comparisons $[24,25]$.

\section{Alaska ecosystem carbon fluxes from 2000 to 2010}

CASA annual NEP on a unit area basis was estimated to be highest $\left(>+10 \mathrm{~g} \mathrm{C} \mathrm{m}^{-2} \mathrm{yr}^{-1}\right.$ ) on average over the period 2000 to 2010 within the Major Land Resource Areas (MRLAs) of the Interior Brooks Range Mountains, the Arctic Foothills, and the Western Brooks Range Mountains (Table 2 and Figure 3). The lowest (negative) mean NEP fluxes from 2000 to 2010 were predicted for the MLRAs of the Cook Inlet Lowlands, the Ahklun Mountains, and Bristol Bay-Northern Alaska Peninsula Lowlands, all in excess of $-4 \mathrm{~g} \mathrm{C} \mathrm{m}^{-2} \mathrm{yr}^{-1}$. The highest variability from year-to-year in predicted NEP flux was estimated within the Seward Peninsula and Yukon-Kuskokwim Highlands MLRAs.

The CASA model predicted three years (2002, 2004, and 2007) during which the highest positive (land $C$ sink) NEP total fluxes totaled to between +2 to $+6 \mathrm{Tg} \mathrm{C} \mathrm{yr}{ }^{-1}$ across individual MLRA regions (Figure 4). Three other years (2001, 2003, and 2006) were predicted with the lowest negative (land C source) NEP total fluxes at between -2 to $-9 \mathrm{Tg} \mathrm{C} \mathrm{yr}^{-1}$ across individual MLRA regions (Figure 4). Not withstanding this high level of interannual variation, CASA mean annual NEP flux over the period 2000 to 2010 for all MLRAs in Alaska was estimated at $+2.4 \mathrm{Tg} \mathrm{C} \mathrm{yr}^{-1}$ (Table 2).

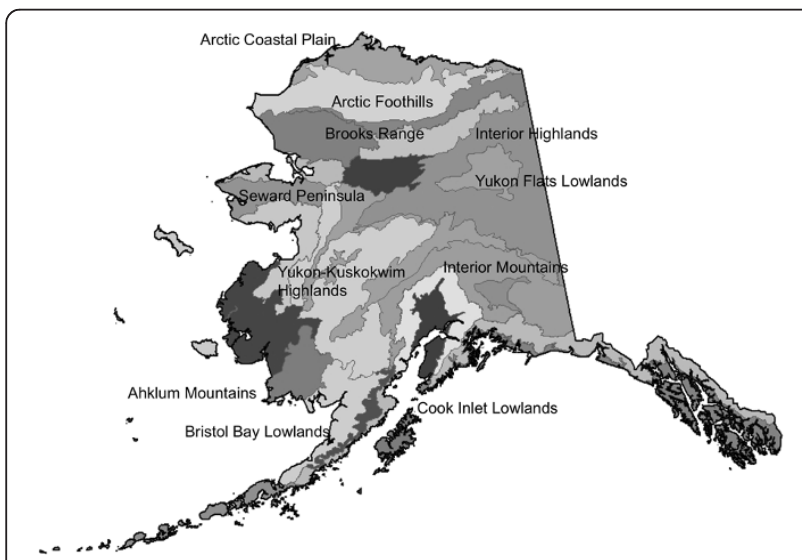

Figure 2 Major Land Resource Areas (MLRAs) of Alaska, with labels for the areas cited in this study.
To help account for the interannual variation in predicted NEP fluxes, four station locations were selected from among the NOAA National Weather Service Aviation Weather Center archive (http://aviationweather.gov) records to represent the climatic and geographic extents of the state, namely the station records from Homer, Nome, Fairbanks, and Barrow Alaska. The years 2002, 2004-2005, and 2007 showed the warmest surface temperature departures over the past decade at all four stations (Figure 5). Temperature departures during 2001 and 2006 were recorded as the coldest over the past decade at all four stations. Precipitation records showed 2001 to be the wettest year over the past decade at the Homer station, whereas 2004-2005 was the wettest period at the Nome and Barrow stations (Figure 6). The 2006 to 2007 period was among the driest at the Barrow station. Precipitation at the Fairbanks station varied from wettest in 2002 and 2003 to driest in 2004 and 2009.

\section{Discussion}

The CASA model results and MODIS EVI time-series data used in this study provided consistent large-scale metrics of vegetation growth and carbon flux trends across the arctic region. We hypothesize from the modeling results presented here that temperature warming-induced inter-annual variability of evapotranspiration (ET) at local and regional scales has altered the rates of ecosystem carbon exchange in Alaska over recent years. In the CASA model, warming-enhanced ET flux during the growing season would increase NEP fluxes during wet years, and would decrease NEP fluxes during dry years $([21,26])$. In further support of this hypothesis, evidence of shrub expansion over the last half century has been documented through repeat photography [27]. Beck and Goetz [14] also postulated that the proportion of North America tundra areas increasing in productivity has steadily grown since 1982, reaching 32\% of non-barren areas in 2008. This regional greening trend appeared to be unrelated to shrub density, indicating that primary productivity is increasing across a range of functional vegetation types.

Recent studies have indicated that wildfires in Alaska can have a large impact on ecosystem carbon stocks, a disturbance flux which we have not addressed in this CASA modeling study. For instance, Yuan et al. [28] reported that soil $\mathrm{C}$ stocks would have increased by 158 Tg C if the Yukon River Basin (YRB) had not undergone warming and changes in fire regime since the 1960s. Tan et al. [29] estimated that YRB wildfires resulted in the total emission of $81 \pm 14 \mathrm{Tg} \mathrm{C} \mathrm{yr}^{-1}$ in 2004 alone, of which $73 \%$ and $27 \%$ could be attributed to the consumption of the ground layer and aboveground biomass, respectively. This fire emission was equivalent to $61 \%$ of the annual biomass $C$ photosynthesized over the YRB study area, assuming the average ecosystem net primary production (NPP) was $266 \mathrm{~g} \mathrm{C} \mathrm{m}^{-2}$ in 2004 [30]. 
Table 2 CASA mean annual NEP flux predictions over the period 2000 to 2010 by the MLRAs in Alaska, sorted by highest (positive: land sink) to lowest (negative: land source) total mean carbon flux

\begin{tabular}{|c|c|c|c|c|}
\hline Major Land Resource Area & $\begin{array}{l}\text { Area } \\
\mathrm{km}^{2} \\
\end{array}$ & $\begin{array}{c}\text { Mean } \\
\mathrm{gC} \mathrm{m}^{-2} \mathrm{yr}^{-1}\end{array}$ & $\begin{array}{l}\text { Standard deviation } \\
\qquad \mathrm{g} \mathrm{C} \mathrm{m}^{-2} \mathrm{yr}^{-1}\end{array}$ & $\begin{array}{c}\text { Total (Mean } \times \text { area) } \\
\mathrm{gC} \mathrm{yr}^{-1}\end{array}$ \\
\hline Arctic Foothills & 108,544 & 12.09 & 4.93 & $1.3 \mathrm{E}+12$ \\
\hline Interior Brooks range mountains & 48,768 & 13.67 & 4.39 & $6.7 \mathrm{E}+11$ \\
\hline Western Brooks range mountains & 59,648 & 10.59 & 5.50 & $6.3 \mathrm{E}+11$ \\
\hline Interior Alaska highlands & 178,624 & 1.89 & 5.22 & $3.4 \mathrm{E}+11$ \\
\hline Northern Brooks range mountains & 41,216 & 7.94 & 5.12 & $3.3 \mathrm{E}+11$ \\
\hline Nulato Hills-Southern Seward Peninsula highlands & 46,400 & 6.76 & 7.67 & $3.1 \mathrm{E}+11$ \\
\hline Seward Peninsula highlands & 34,368 & 8.26 & 7.20 & $2.8 \mathrm{E}+11$ \\
\hline Northern Seward Peninsula-Selawik lowlands & 20,736 & 9.00 & 5.68 & $1.9 \mathrm{E}+11$ \\
\hline Upper Kobuk and Koyukuk hills and valleys & 34,240 & 2.86 & 4.02 & $9.8 \mathrm{E}+10$ \\
\hline Arctic Coastal plain & 58,496 & 1.27 & 4.08 & $7.4 \mathrm{E}+10$ \\
\hline Southern Alaska coastal mountains & 67,392 & 0.33 & 1.97 & $2.2 \mathrm{E}+10$ \\
\hline Copper River Basin & 11,840 & 0.36 & 1.69 & $4.3 \mathrm{E}+09$ \\
\hline Northern Bering Sea Islands & 9,216 & -0.72 & 2.53 & $-6.6 \mathrm{E}+09$ \\
\hline Yukon Flats lowlands & 32,704 & -0.49 & 2.61 & $-1.6 \mathrm{E}+10$ \\
\hline Southern Alaska Peninsula mountains & 15,680 & -1.26 & 2.59 & $-2.0 \mathrm{E}+10$ \\
\hline Interior Alaska mountains & 114,496 & -0.30 & 2.78 & $-3.5 E+10$ \\
\hline Northern Alaska Peninsula mountains & 14,400 & -2.47 & 2.59 & $-3.6 \mathrm{E}+10$ \\
\hline Kodiak Archipelago & 12,352 & -3.10 & 3.68 & $-3.8 \mathrm{E}+10$ \\
\hline Aleutian Islands-Western Alaska Peninsula & 25,024 & -2.96 & 4.71 & $-7.4 \mathrm{E}+10$ \\
\hline Cook Inlet mountains & 51,008 & -1.98 & 3.80 & $-1.0 \mathrm{E}+11$ \\
\hline Alexander Archipelago-Gulf of Alaska Coast & 66,944 & -1.60 & 3.92 & $-1.1 \mathrm{E}+11$ \\
\hline Interior Alaska lowlands & 93,696 & -1.21 & 3.99 & $-1.1 \mathrm{E}+11$ \\
\hline Cook Inlet lowlands & 27,328 & -6.19 & 4.33 & $-1.7 \mathrm{E}+11$ \\
\hline Ahklun mountains & 37,760 & -5.27 & 2.59 & $-2.0 \mathrm{E}+11$ \\
\hline Yukon-Kuskokwin coastal plain & 76,864 & -2.68 & 2.78 & $-2.1 \mathrm{E}+11$ \\
\hline Bristol Bay-Northern Alaska Peninsula lowlands & 50,176 & -4.51 & 3.15 & $-2.3 \mathrm{E}+11$ \\
\hline Yukon-Kuskokwim highlands & 155,072 & -3.16 & 5.95 & $-4.9 \mathrm{E}+11$ \\
\hline State total & $1,492,992$ & & & $2.4 \mathrm{E}+12$ \\
\hline
\end{tabular}

Previous simulation modeling studies of carbon storage for Alaska estimated that terrestrial ecosystems have been a net sink (from the atmosphere) of between +5 and $+12 \mathrm{Tg} \mathrm{C}$ in the 1980s, and between 0 and +10 $\mathrm{Tg} \mathrm{C} \mathrm{yr}^{-1}$ during the 1990s $[18,19]$. The CASA model results since 2000 presented in this study indicated that there has been a high level of interannual variability within those previously estimated ranges, fluctuating around an

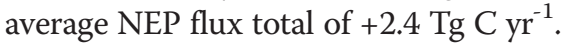

In answer to the question of how climate variability has affected patterns of ecosystem carbon storage in Alaska, we may conclude from the CASA model results that the relatively warm and wet years of 2004 and 2007 resulted in the highest positive NEP flux totals across MLRAs in the northern and western coastal locations in the state (i.e., the Brooks Range Mountains and Arctic Foothills).
The relatively cold and dry years of 2001 and 2006 were predicted with the lowest (negative) NEP flux totals for these MLRAs, and likewise across the Ahklun Mountains and the Yukon-Kuskokwim Highlands.

In answer to the question of which ecosystems or landscape components in Alaska were most vulnerable to abrupt loss of ecosystem carbon over the past decade, it was evident from the CASA model results presented here that the Interior Highlands and the Yukon-Kuskokwim Highlands have experienced the greatest annual declines and interannual variations in NEP total flux over the past decade. As for which ecosystems were the most resistant to abrupt loss of ecosystem carbon, we can hypothesize from the CASA model results that the Arctic Foothills ecosystems have not released as much $\mathrm{CO}_{2}$ to the atmosphere during warm/dry periods as have other MLRAs in Alaska. 


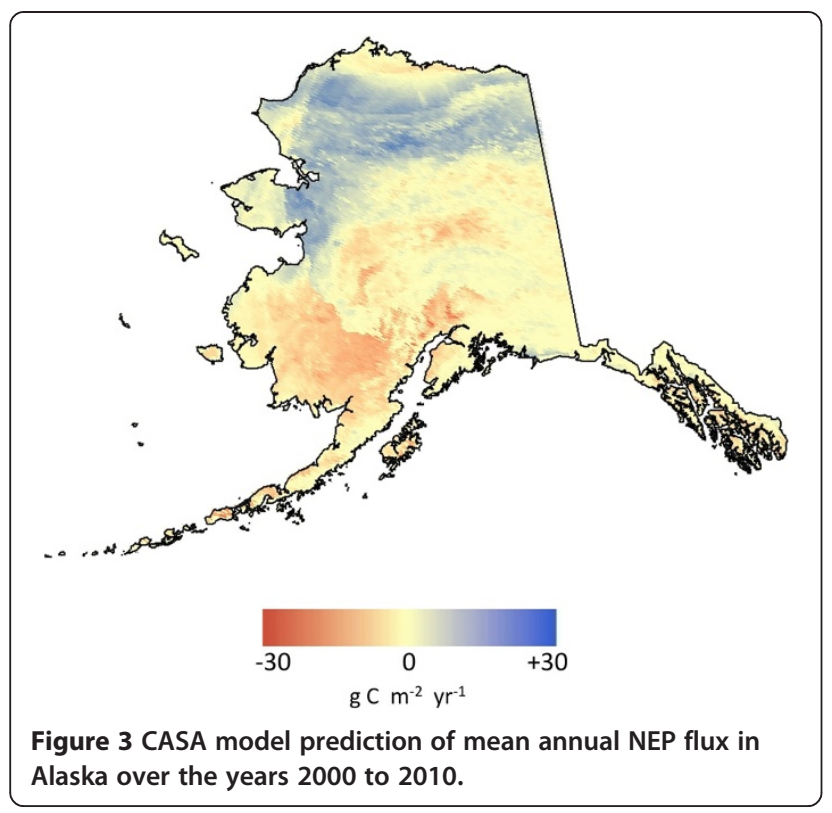

It should be noted that Wang et al. [31] reported on sensor degradation having had an impact on trend detection in North America boreal and tundra zone NDVI with Collection 5 data from MODIS. The main impacts of gradual blue band (Band 3, $470 \mathrm{~nm}$ ) degradation on simulated surface reflectance was most pronounced at near-nadir view angles, leading to a small decline (0.001-0.004 $\mathrm{yr}^{-1} ; 5 \%$ overall between 2002 and 2010) in NDVI under a range of simulated aerosol conditions and high-latitude surface types. Even if this same sensor degradation problem affected MODIS EVI trends over the period of our analysis from 2000 to 2010 (which has not been reported in a publication), the apparent rate of greening in ecosystems of Alaska was evidently not negated by such small, progressive changes in MODIS data quality [32].

In closing, the CASA modeling methodology developed for mapping and characterization of ecosystem carbon fluxes can be readily extended over the upcoming decade of Collection 6 MODIS EVI data. The next set of CASA runs for Alaska will incorporate new statewide mapping of wetland types developed by Whitcomb et al. [33] to generate $1-\mathrm{km}$ resolution flux estimates of methane $\left(\mathrm{CH}_{4}\right)$ emissions. These simulations will follow the CASA wetland NEP modeling methods published by Potter et al. [34] for the continental United States coverage. We will thereby be well-positioned to answer the research question of how land surface hydrology patterns (specifically related to wetlands) interact with vegetation, topography, and permafrost
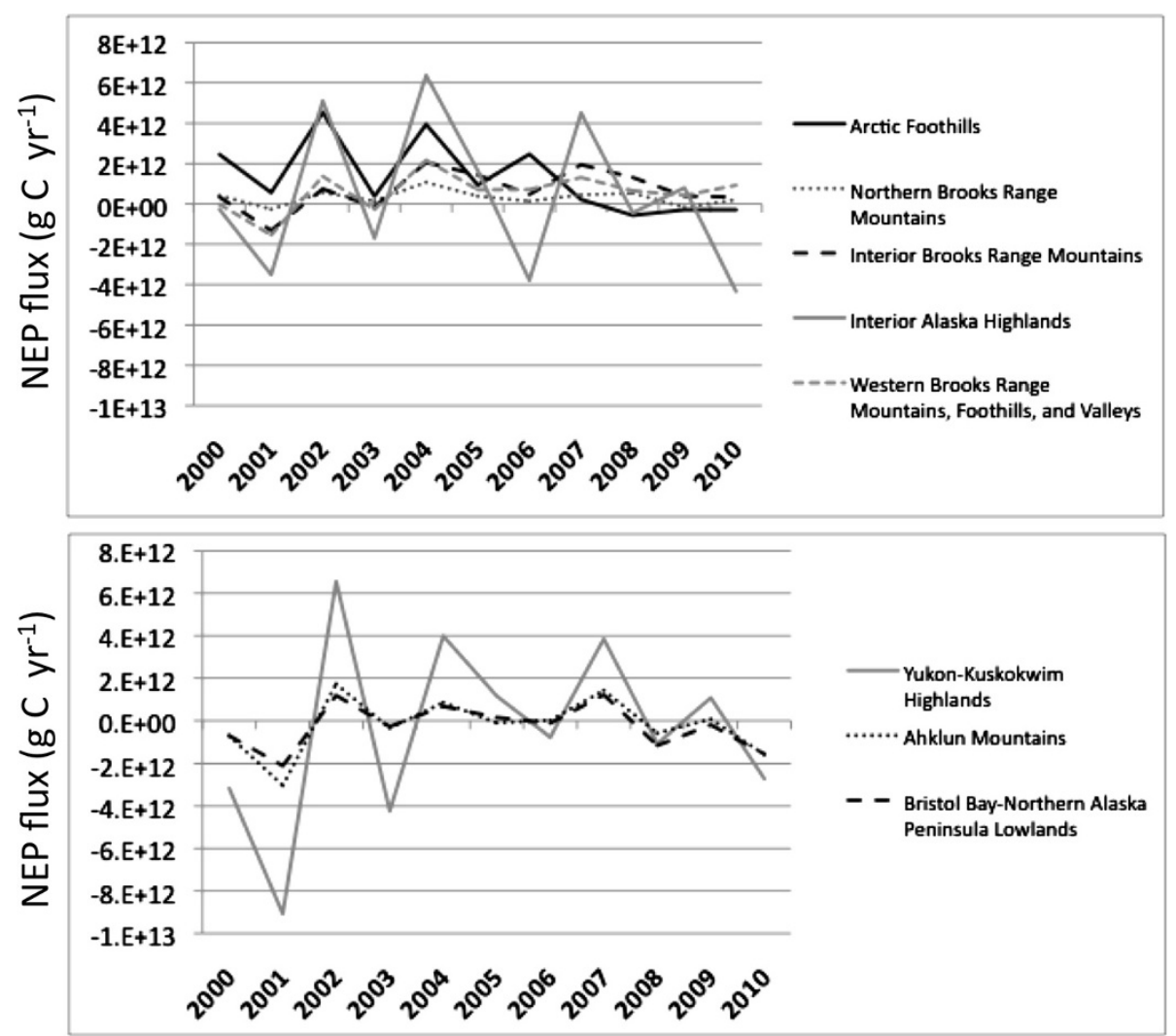

Figure 4 Yearly (2000 to 2010) variability in CASA model predicted NEP for selected MLRAs in Alaska. 

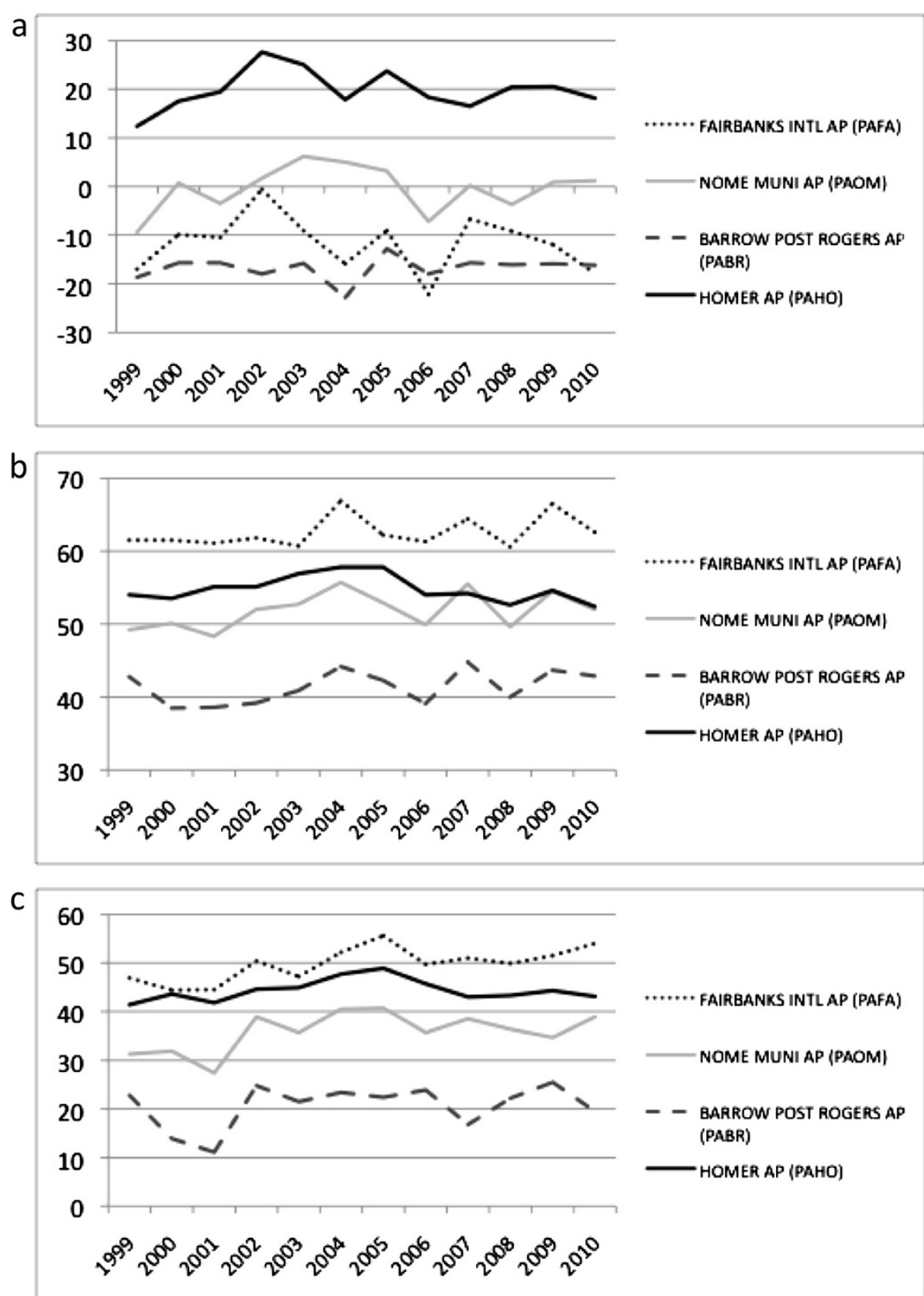

Figure 5 Surface temperature variations (2000 to 2010, in degrees F) from selected Alaska weather stations, (a) minimum, (b) maximum, (c) May of each year.

to influence both $\mathrm{CO}_{2}$ and $\mathrm{CH}_{4}$ emissions in northern latitude ecosystems.

\section{Methods}

Monthly NPP of vegetation from the CASA model was predicted using the relationship between greenness reflectance properties and the fraction of absorption of photosynthetically active radiation (fPAR), assuming that net conversion efficiencies of PAR to plant carbon can be approximated for different ecosystems or are nearly constant across all ecosystems [35-37]. For this study, we used MODIS collection 5 of the Enhanced Vegetation Index (EVI; [38]) as model inputs for PAR interception, aggregated for regional assessments to an $8-\mathrm{km}$ spatial resolution.

As documented in Potter [39-41], monthly production of plant biomass is estimated as a product of time-varying surface solar irradiance, Sr, and EVI (for fPAR) from the MODIS sensor, plus a constant light utilization efficiency term (emax) that is modified by time-varying stress 

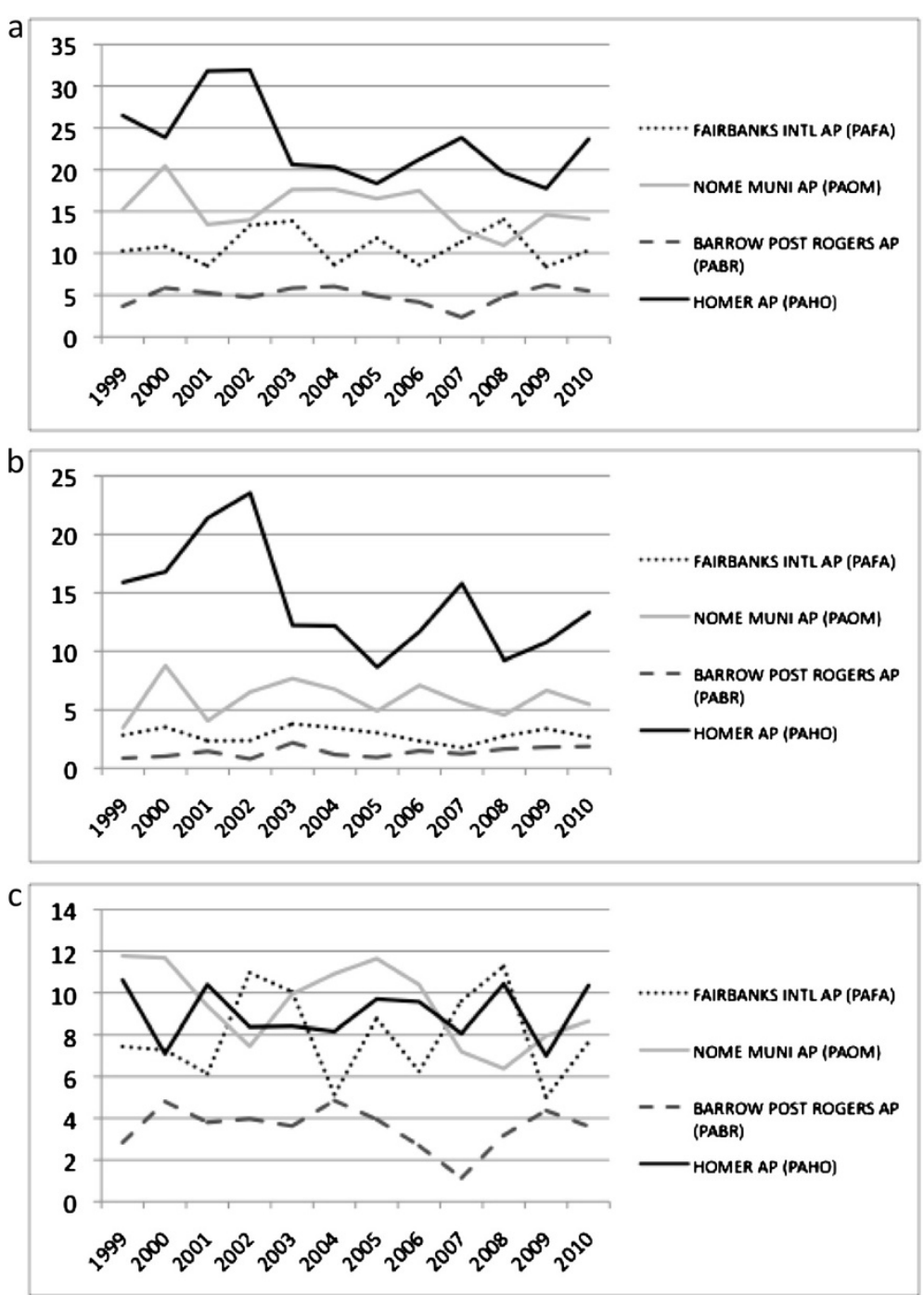

Figure 6 Total precipitation variations (2000 to 2010, in inches) from selected Alaska weather stations, (a) annual, (b) winter, (c) summer.

scalar terms for temperature (T) and moisture (W) effects (Equation 1).

$$
\mathrm{NPP}=\mathrm{Sr} \text { EVI emax T W }
$$

The CASA emax term was set uniformly at $0.55 \mathrm{~g} \mathrm{C} \mathrm{MJ}^{-1}$ PAR, an approach that derives from calibration of predicted annual NPP to previous field estimates [42]. This model setting has been successfully validated globally by comparing predicted annual NPP to more than 1900 field measurements of NPP [43], and against numerous Fluxnet eddy covariance tower site measurements of NPP from 2000-2007 [26]. Gridded monthly climate inputs for these CASA runs were from National Center for Environmental Prediction (NCEP) reanalysis products (version NCEP/DOE II; $[44,45]$ ).

The CASA model is designed to couple daily and seasonal patterns in soil nutrient mineralization and soil heterotropic respiration ( $\mathrm{Rh}$ ) of $\mathrm{CO}_{2}$ from soils. The CASA soil carbon model uses a set of compartmental difference equations [43]. First-order decay equations simulate exchanges of decomposing plant residue (metabolic and structural fractions) at the soil surface. The model also simulates surface soil organic matter (SOM) fractions that presumably vary in age and chemical composition. Turnover of active (microbial biomass and labile substrates), slow (chemically protected), and passive (physically protected) fractions of the SOM are represented. CASA includes boreal forest floor organic layers (ground moss) and soil freeze/thaw (permafrost) dynamics in its simulation of ecosystem carbon flux $[46,47]$. The soil pools are initialized for global CASA model runs with a 3600 monthly time step "spin-up" routine, based on average monthly climate drivers representing the late 1990s. 
Monthly and annual NEP was computed as NPP minus $\mathrm{Rh}$ fluxes, excluding the contributions of forest fires and other localized disturbances to ecosystem $\mathrm{CO}_{2}$ source emissions. Global CASA NEP predictions have been validated previously against numerous temperate and tropical ecosystem measurements of NEP from eddy covariance tower sites from 2000-2007 [21]. Sensitivity and uncertainty analysis has been conducted previously for the CASA model in northern ecosystems, along with numerous other carbon models as part of the NASA-BOREAS campaign [48].

Collection 5 MODIS data sets beginning in the year 2000 were obtained from NASA's Land Processes Distributed Active Archive Center site [49]. MODIS EVI values were aggregated to $8-\mathrm{km}$ resolution from MOD13C2 (MODIS/Terra Vegetation Indices) products. MOD13C2 data are cloud-free spatial composites of the gridded 16-day 1-kilometer MOD13A2 product, and were provided monthly as a level- 3 product projected on a 0.05 degree (5600-meter) geographic Climate Modeling Grid (CMG). Cloud-free global coverage at $8-\mathrm{km}$ spatial resolution was achieved by replacing clouds with the historical MODIS time-series EVI record. MODIS EVI was calculated from red, blue and NIR bands as described by Huete et al. [50]. MODIS EVI was scaled from its original values to a range of 0 to 1 for CASA model inputs.

\section{Competing interests}

The authors declare that they have no competing interests.

\section{Authors' contributions}

All authors have made substantial contributions to the acquisition of data, analysis and interpretation of results, drafting the manuscript, and have given final approval of the version to be published.

\section{Acknowledgements}

This work was conducted with the support from NASA under the U. S. National Climate Assessment.

\section{Author details}

'NASA Ames Research Center, Mail Stop 232-21, Moffett Field, CA 94035, USA. ${ }^{2}$ California State University Monterey Bay, Seaside, CA, USA.

Received: 6 August 2013 Accepted: 19 November 2013

Published: 22 November 2013

\section{References}

1. IPCC: Climate Change 2007: Synthesis Report. Contribution of Working Groups I, II and III to the Fourth Assessment Report of the Intergovernmental Panel on Climate Change. Geneva, Switzerland: IPCC; 2007:104

2. Callaghan TV, Björn LO, Chapin FS III, Chernov Y, Christensen TR, Huntley B, Ims R, Johansson M, Riedlinger DJ, Jonasson S, Matveyeva N, Oechel W, Panikov N, Shaver G: Arctic Tundra and Polar Desert Ecosystems. Chapter 7. In Arctic Climate Impact Assessment. Cambridge University: Arctic Council; 2005:243-352.

3. Martin PD, Jenkins $\mathrm{LL}$, Adams FJ, Jorgenson MT, Matz AC, Payer DC, Reynolds PE, Tidwell AC, Zelenak JR: Wildlife Response to Environmental Arctic Change: Predicting Future Habitats of Arctic Alaska. In Report of the Wildlife Response to Environmental Arctic Change (WildREACH): Predicting Future Habitats of Arctic Alaska Workshop, 17-18 November 2008. Fairbanks, Alaska: U.S: Fish and Wildlife Service; 2009:138.
4. Reist JD, Wrona FJ, Prowse TD, Power M, Dempson JB, Beamish RJ, King JR Carmichael TJ, Sawatzky CD: General effects of climate change on Arctic fishes and fish populations. Ambio 2006, 35:370-380.

5. Root TL, Price JT, Hall KR, Schneider SH, Rosenzweig C, Pounds JA: Fingerprints of global warming on wild animals and plants. Nature 2003, 421(6918):57-60.

6. Thackeray SJ, Sparks TH, Frederiksen M, Burthe S, Bacon PJ, Bell JR, Botham MS, Brereton TM, Bright PW, Carvalho L, Clutton-Brock T, Dawson A, Edwards M, Elliott JM, Harrington R, Johns D, Jones ID, Jones JT, Leech DI, Roy DB, Scott WA, Smith M, Smithers RJ, Winfield IJ, Wanless S: Trophic level asynchrony in rates of phenological change for marine, freshwater and terrestrial environments. Glob Chang Biol 2010. doi:10.1111/j.1365-2486.2010.02165.x.

7. Amiro BD, Chen JM, Liu J: Net primary productivity following forest fire for Canadian ecoregions. Can J Forest Res 2000, 30(6):939-947.

8. Casady GM, Marsh SE: Broad-scale environmental conditions responsible for post-fire vegetation dynamics. Remote Sensing 2010, 2(12):2643-2664.

9. Cuevas-Gonzalez M, Gerard F, Balzter H, Riano D: Analysing forest recovery after wildfire disturbance in boreal Siberia using remotely sensed vegetation indices. Glob Chang Biol 2009, 15:561-577. doi:10.1111/j.1365-2486.2008.01784.x.

10. Epting J, Verbyla DL: Landscape level interactions of pre-fire vegetation, burn severity, and post-fire vegetation over a 16-year period in interior Alaska. Can J Forest Res 2005, 35:1367-1377.

11. Jia GJ, Epstein HE, Walker DA: Greening of arctic Alaska, 1981-2001. Geophys Res Lett 2003, 30(20):2067. doi:10.1029/2003GL018268.

12. Goetz SJ, Bunn AG, Fiske GJ, Houghton RA: Satellite observed photosynthetic trends across boreal North America associated with climate and fire disturbance. Proc Natl Acad Sci 2005, 103(38):13521-13525.

13. Goetz SJ, Fiske GJ, Bunn AG: Using satellite time-series data sets to analyze fire disturbance and forest recovery across Canada. Remote Sens Environ 2006, 101:352-365.

14. Beck PSA, Goetz SJ: Satellite observations of high northern latitude vegetation productivity changes between 1982 and 2008: ecological variability and regional differences. Environ Res Lett 2011, 6:045501.

15. Walker $\mathrm{MD}$, et al: Plant community responses to experimental warming across the tundra biome. Proc Natl Acad Sci 2006, 103:1342-1346.

16. McMichael CE, Hope AS, Stow DA, Fleming JB: The relation between active layer depth and a spectral vegetation index in arctic tundra landscapes of the North Slope of Alaska. Int j remote sens 1997, 18(11):2371-2382.

17. Kim Y, Kimball JS, Zhang K, McDonald KC: Satellite detection of increasing northern hemisphere non-frozen seasons from 1979 to 2008 : implications for regional vegetation growth. Remote Sens Environ 2012, 121:472-487.

18. Balshi MS, McGuire AD, Zhuang Q, Melillo J, Kicklighter DW, Kasischke E, Wirth C, Flannigan M, Harden J, Clein JS, Burnside TJ, McAllister J, Kurz WA, Apps M, Shvidenko A: The role of historical fire disturbance in the carbon dynamics of the pan-boreal region: a process based analysis. J Geophys Res 2007, 112, G02029.

19. Zhuang Q, Melillo JM, McGuire AD, Kicklighter DW, Prinn RG, Steudler PA, Felzer BS, Hu S: Net emissions of $\mathrm{CH}_{4}$ and $\mathrm{CO}_{2}$ in Alaska: implications for the region's greenhouse gas budget. Ecol Appl 2007, 17:203-212.

20. O'Donnell JA, Jorgenson MT, Harden JW, McGuire AD, Kanevskiy MZ, Wickland KP: The effects of permafrost thaw on soil hydrologic, thermal and carbon dynamics in an Alaskan peatland. Ecosystems 2012, 15:213-229. doi:10.1007/s10021-011-9504-0.

21. Potter C, Klooster S, Genovese V, Hiatt C, Boriah S, Kumar V, Mithal V, Garg A: Terrestrial ecosystem carbon fluxes predicted from MODIS satellite data and large-scale disturbance modeling. International Journal of Geosciences 2012. doi:10.4236/ijg.2012.

22. Friedl MA, Mclver DK, Hodges JCF, Zhang XY, Muchoney D, co-authors: Global land cover mapping from MODIS: algorithms and early results. Remote Sens Environ 2002, 83:287-302.

23. USDA Natural Resources Conservation Service: Land Resource Regions and Major Land Resource Areas (MRLAs) of the United States, the Caribbean, and the PacificBasin. U.S: Department of Agriculture Handbook; 2006:296.

24. Heinsch FA, Zhao MS, Running SW, Kimball JS, Nemani RR: Evaluation of remote sensing based terrestrial productivity from MODIS using tower eddy flux network observations. leee $t$ geosci remote 2006, 44:1908-1924. 
25. Ma S, Baldocchi DD, Xu LK, Hehn T: Inter-annual variability in carbon dioxide exchange of an Oak/grass savanna and open grassland in California. Agr Forest Meteorol 2007, 147:157-171.

26. Potter C, Klooster $\mathrm{S}$, Genovese $\mathrm{V}$ : Net primary production of terrestrial ecosystems from 2000 to 2009. Clim Change 2012. doi:10.1007/s10584-0120460-2.

27. Tape K, Sturm M, Racine C: The evidence for shrub expansion in northern Alaska and the pan-Arctic. Glob Chang Biol 2006, 12:686-702

28. Yuan FM, Yi SH, McGuire AD, Johnson KD, Liang J, Harden JW, Kasischke ES, Kurz WA: Assessment of boreal forest historical $C$ dynamics in the Yukon River Basin: relative roles of warming and fire regime change. Ecol Appl 2012, 22(8):2091-109.

29. Tan Z, Tieszen LL, Zhu Z, Liu S, Howard SM: An estimate of carbon emissions from 2004 wildfires across Alaskan Yukon River Basin. Carbon Balance Manag 2007, 2:12.

30. van der Werf GR, Randerson JT, Giglio L, Collatz GJ, Kasibhatla PS, Kasibhatla PS, Arellano AF Jr: Interannual variability in global biomass burning emissions from 1997 to 2004. Atmos Chem Phys 2006, 6:3423-3441.

31. Wang D, Morton D, Masek J, Wu A, Nagol J, Xiong X, Levy R, Vermote $E$, Wolfe R: Impact of sensor degradation on the MODIS NDVI time series. Remote Sens Environ 2012, 119:55-61.

32. Potter C, Li S, Crabtree R: Changes in Alaskan tundra ecosystems estimated from MODIS greenness trends, 2000 to 2010. Journal of Geophysics \& Remote Sensing 2013, 2:1. http://dx.doi.org/10.4172/2169-0049.1000107.

33. Whitcomb J, Moghaddam M, McDonald K, Kellndorfer J, Podest E: Mapping wetlands of Alaska from L-band SAR imagery. Can j remote sens 2009, 35:54-72.

34. Potter C, Klooster S, Hiatt S, Fladeland M, Genovese V, Gross P: Methane emissions from natural wetlands in the United States: satellite-derived estimation based on ecosystem carbon cycling. Earth interact 2006, 10(22):1-12

35. Goetz SJ, Prince SD: Variability in light utilization and net primary production in boreal forest stands. Can J Forest Res 1998, 28:375-389.

36. Running SW, Nemani RR, Heinsch FA, Zhao M, Reeves M, Hashimoto $H$ A continuous satellite-derived measure of global terrestrial primary production. BioScience 2004, 54:547-560.

37. Sellers PJ, Tucker CJ, Collatz GJ, Los SO, Justice CO, Dazlich DA, Randall DA: A global 1x1 NDVI data set for climate studies. Part 2: the generation of global fields of terrestrial biophysical parameters from the NDVI. Int $j$ remote sens 1994, 15:3519-3545.

38. Huete AR, Didan K, Shimabukuro YE, Ratana P, Saleska SR, Hutyra LR, Fitzjarrald D, Yang W, Nemani RR, Myneni R: Amazon rainforests green-up with sunlight in dry season. Geophys Res Lett 2006, 33:L 06405. doi:10.1029/2005GL025583.

39. Potter CS, Brooks V: Global analysis of empirical relations between annual climate and seasonality of NDVI. Int j remote sens 1998, 19:2921-2948.

40. Potter CS: Terrestrial biomass and the effects of deforestation on the global carbon cycle. BioScience 1999, 49:769-778.

41. Potter CS, Klooster SA, Brooks V: Interannual variability in terrestrial net primary production: exploration of trends and controls on regional to global scales. Ecosystems 1999, 2:36-48.

42. Potter CS, Randerson JT, Field CB, Matson PA, Vitousek PM, Mooney HA, Klooster SA: Terrestrial ecosystem production: a process model based on global satellite and surface data. Glob Biogeochem Cycles 1993, 7:811-41.

43. Potter C, Klooster S, Myneni R, Genovese V, Tan P, Kumar V: Continental scale comparisons of terrestrial carbon sinks estimated from satellite data and ecosystem modeling 1982-98. Global Planet Change 2003, 39:201-213.

44. Kalnay E, Kanamitsu M, Kistler R, Collins W, Deaven D, Gandin L, Iredell M, Saha S, White G, Woollen J, Zhu Y, Leetmaa A, Reynolds B, Chelliah M, Ebisuzaki W, Higgins W, Janowiak J, Mo KC, Ropelewski C, Wang J, Jenne R, Joseph D: The NCEP/NCAR 40-year reanalysis project. Bull Am Meteorol Soc 1996, 77:437-472.

45. Kistler R, et al: The NCEP-NCAR 50-year reanalysis: monthly means CD-ROM and documentation. Bull Am Meteorol Soc 2001, 82:247-68.

46. Potter CS, Wang S, Nikolov NT, McGuire AD, Liu J, King AW, Kimball JS, Grant RF, Frolking SE, Clein JS, Chen JM, Amthor JS: Comparison of boreal ecosystem model sensitivity to variability in climate and forest site parameters. J Geophys Res 2001, 106:33,671-33,688.

47. Potter CS: Predicting climate change effects on vegetation, soil thermal dynamics, and carbon cycling in ecosystems of interior Alaska. Ecol Model 2004, 175:1-24.
48. Potter CS, Bubier J, Crill P, LaFleur P: Ecosystem modeling of methane and carbon dioxide fluxes for boreal forest sites. Can J Forest Res 2001, 31:208-223

49. LP-DACC: NASA Land Processes Distributed Active Archive Center. In MODIS/Terra Vegetation Indices Monthly L3 Global 0.05Deg CMG (MOD13C2), Version 005. Sioux Falls, South Dakota: USGS/Earth Resource s Observation and Science (EROS) Center; 2007.

50. Huete A, Didan K, Miura T, Rodriquez E, Gao X, Ferreira L: Overview of the radiometric and biophysical performance of the MODIS vegetation indices. Remote Sens Environ 2002, 83:195-213.

doi:10.1186/1750-0680-8-12

Cite this article as: Potter et al:: Alaska ecosystem carbon fluxes estimated from MODIS satellite data inputs from 2000 to 2010. Carbon Balance and Management 2013 8:12.

\section{Submit your next manuscript to BioMed Central and take full advantage of:}

- Convenient online submission

- Thorough peer review

- No space constraints or color figure charges

- Immediate publication on acceptance

- Inclusion in PubMed, CAS, Scopus and Google Scholar

- Research which is freely available for redistribution 